\title{
Examining Selected Newspapers' Framing of the Renewed Biafran Agitation in Nigeria (2016 - 2017)
}

\author{
Victor Chinedu Eze \\ Department of Communication and Language Arts, University of Ibadan - viccjohnson@gmail.com
}

\begin{abstract}
The renewed Biafran agitation headed by Indigenous People of Biafra (IPOB) has been in the news since 2016. This is surprising when one considers that the Nigerian-Biafran war was fought over 50 years ago with no victor and no vanquished stance. This research examines how selected newspapers framed the Biafran agitation from January, 2016 to December, 2017 - a period which recorded a spike in the activities of Biafran agitators who called for a referendum to carve out the Republic of Biafra. Framing theory is employed as the theoretical frame work for this research. Four hundred and twenty-one (421) issues of selected newspapers were sampled

through purposive and critical case sampling techniques. The data were analysed through qualitative and quantitate content analysis. Findings of this research showed that selected newspapers framed the agitation from political, economic, separatist, human rights, conflict and hate speech frames. Findings also show that media correspondents were the primary frame source for stories on the renewed Biafran agitation. The print media perceived the agitation mainly from human rights crisis where the agitators are deprived of the freedom to protest and are dehumanised by the Nigerian security operatives; and questioned the government over human rights abuses.
\end{abstract}

Keywords: Biafra, framing, Nigeria, agitation, session, media.

\section{Examinando os Enquadramentos Noticiosos de Jornais Selecionados da Renovada Agitação Biafrense na Nigéria (2016-2017)}

\section{Sumário}

A renovada agitação biafrense liderada pelos Povos Indígenas de Biafra (IPOB) tem sido notícia desde 2016. Isto é surpreendente quando se considera que a guerra nigerianabiafrense foi travada há mais de 50 anos, sem vitórias e nenhuma posição vencida. Esta investigação examina como os jornais selecionados enquadraram a agitação de janeiro de
2016 a dezembro de 2017 - um período que registou um pico nas atividades dos agitadores briafenses, que pediram um referendo para possibilitar criação da República de Biafra. A teoria do enquadramento é o quadro teórico desta pesquisa. Quatrocentos e vinte e um (421) números de jornais foram selecionados por meio de técnicas de amostragem 
de casos críticos e intencionais. Os dados foram analisados através de análise de conteúdo qualitativa e quantitativa. Os resultados deste estudo mostraram que os jornais selecionados enquadravam a agitação em quadros políticos, económicos, separatistas, de direitos humanos, conflito e discurso de ódio. Os resultados também mostram que os correspondentes da imprensa eram a fonte prin- cipal para artigos sobre a renovada agitação biafrense. Os media impressos noticiaram a agitação da crise principalmente a partir dos direitos humanos, em que os agitadores são privados da liberdade de protestar e são desumazinados pelos agentes de segurança nigeriados, questionando o governo por violações dos direitos humanos

Palavras-chave: Biafra, enquadramento, Nigeria, agitação, sessão, media.

\section{INTRODUCTION}

Since the end of the Nigerian Civil war in 1970 tagged the Biafran war, pain, losses and regrets have continued to linger in the minds of both those who stood by the Nigerian side and those who fought on the Biafran side at that time. While it is expected that the open wounds about the Biafran struggles would have been healed after the war which lasted from July 6, 1967 to January 15, 1970 (Akpan, 1976), the Nigerian government over the years seem not to have done enough to pacify frail nerves. Instead of bringing the Biafrans to a round table for dialogue, the government resorts to intimidation and gagging of voices - such as Indigenous People of Biafra (IPOB) - that get vocal about the Biafran agitation. IPOB is a splinter organization from Movement for the Actualisation on Sovereign State of Biafra (MASSOB) led by Nnamdi Kanu (Dixon, 2016). Members of IPOB perceive themselves as Biafran activists and engage in the renewed call for the Biafran nation. They clamor for a referendum where individuals from the Igbo ethnic nation will decide whether or not to remain in Nigeria as members of one united nation (Hegarty, 2017). In the ensuing agitation by the group, several members of IPOB have been killed by the Nigerian security agencies. Amnesty International blamed the Nigerian Army for the death of more than 100 members of IPOB in Anambra state during the celebration of Biafra Remembrance day from May, 29 to 30, 2016 and in February during a prayer service (Amnesty International, 2016). 
The leader of IPOB, Nnamdi Kanu, was jailed for two years and was released on bail in 2017. He disappeared after the Nigerian security agencies besieged his hometown to put an end to the increasing threat to election boycott and other activities of the group who appeared to be gaining the attention of international community, local media and international media groups by day. On 20 September, 2017, the Nigerian government secured a court injunction from the Federal High Court, in Abuja, banning the activities of IPOB and branding it a terrorist organization (Channels $\mathrm{Tv}$, 2017). That move has attracted condemnation from several individuals since IPOB members do not bear arms.

\section{STATEMENT OF THE PROBLEM}

According to the Nigeria Watch database, from 2006 to 2019, the number of fatalities resulting from the Biafran agitation related killings stands at one thousand one hundred and twelve $(1,112)$ deaths in 72 incidents. Anambra State in the South East experienced the highest number of Biafra related deaths which is $75 \%$ (831 deaths). Most of the killings were extra-judicial killings by the security personnel who shoot at the agitators. Nigeria Watch (www.nigeriawatch.org) is an online database which monitors and indexes data from lethal violence, conflicts and human security in $\mathrm{Ni}$ geria.

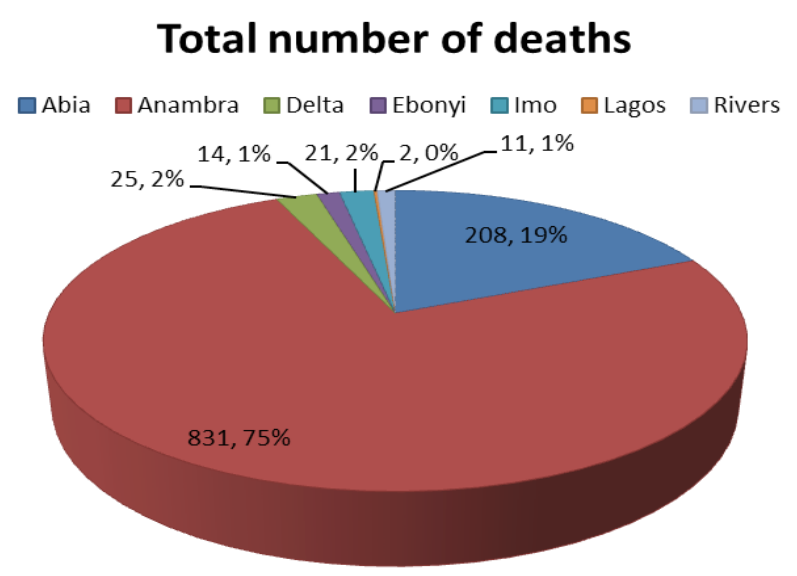

Figure 1. Biafran agitation Related fatalities by states (2006-2019) from NigeriaWatch database, 2019 
Furthermore, after 50 years of war, the Biafran narrative is again resurrecting in the Nigerian society in different way that appear resounding to both the agitators and the Nigerians with the advent of Indigenous People of Biafra (IPOB) by Mazi Nnamdi Kanu. Since the renewed struggles of the agitators commenced, in 2015, the media have been instrumental in the reportage of the clamor for a new Biafran State, as increased attention is given to the Biafra agitation story in different media. This study examines the framing of the renewed Biafran agitation from 2016-2017 in selected newspapers (Daily Trust and Punch newspapers) and captures how they framed the agitation.

\section{LITERATURE REVIEW}

Some researchers and scholars have investigated and written extensively on the concept of secession in different parts of the world. According to Tir, secession is defined as "an attempt to resolve a domestically based territorial dispute by dividing a country's homeland territory into new, secessionist (e.g., Eritrea) and rump (e.g., Ethiopia) states. Yet, the secession may not have resolved the original dispute to the states' satisfaction." Tir $(2005$, p. 11) further underscored that after secession, the leader of the rump state could attempt to employ force to retake part of the land taken over by the secessionist state, while the head of secessionist state is encouraged in the movement by the cache of land acquired by his movement. The author found that ethnically rooted territorial disputes play a much greater role in onset of conflict than do their economically or strategically based and that secession could either be peaceful - leading to a peaceful relations afterwards - or violent - resulting to conflict and wars.

Apart from the Biafran agitation, several secessionist movements have been recorded. Some of these were witnessed and are still being witnessed in places such as Scotland, Catalonia, Iraqi Kurdistan, New Caledonia, and Bougainville (Griffiths, 2017). For these units, there are several attempts to break off from the country in which the actors find themselves.

Investigating secession movement from 1900 to 2006, Griffiths and Waser highlighted that recent research indicates that "the strategic use of violence may increase a group's chance of gaining independence" (2018, p. 1). The researchers examined the primary data set on the institutional and extra-institutional approaches that seces- 
sionists employed from 1946 to 2011 and found that there are differences in secessionist movements. Their studies revealed that secessionists have several institutional or legal channels towards independence which inform their movements. They also discovered that no secessionist movement seeking for independence from a contiguous state has achieved that without employing institutional approaches only or in conjunction with extra-institutional approach.

Sorens (2005) analyzed the risk factors of secessionism at sub-state and regional level by finding out the regions that are more likely to support more successful secessionist parties. The researcher found that secessionism has unique factors that are associated with it which are quite different from other forms of ethnic conflict. The identified factors which help to strength secession are language, lack of irredentist potential, relative affluence, geographical non-contiguity, population, and multiparty political system. These factors generally serve as activators of ethnic identity rather than a substitute for the same, although there are important cases of non-ethnic secessionism. Thus, in the views of Sorens (2005), ethnicity plays a major role in secession.

In addition, Criado, Herreros, Miller and Ubeda (2018) found that ethnicity and trust are ingredients which fuel secessionist movements. They conjectured that political competition could strengthen ethnic saliency and, in turn, salient ethnic identities can activate or intensify in-group trust and depress trust in members of other ethnic groups. Under studying the pre and post secession periods in Catalonia, Spain, the researchers discovered that ethnicity helps to build trust among groups and the reverse could ignite secession movements.

Still buttressing the factor of ethnicity, Hentschel (2018) observed that one of the root causes of secession movement is the quest by ethnic groups to steer above implemented national policies that demean them. Thus, ethnic groups employ session as an instrument for eliminating ethnic heterogeneity cost and so adopt their own policy. The scholar learned that further secessionist conflicts will more likely lead to more session as there will be more quests among the segregating units to secede from the whole.

Examining secession from the religious dimension, Sari (2018) investigated Indonesia's involvement in Muslim-related secessions in non-Muslim countries. The study found that the way Indonesian government relates Muslim separatists and their host countries depend on the perception of the key policy makers' perception that support or non-support can affect national interest. Thus, support for secessionists is not based on affiliations but on the supporting nation's interests. 
In all, Hecter postulates that secession is a rational choice which is an "outcome of series of collective decisions made by regional leaders and populations, and by the leaders and populations of host states" (1992, p. 1). Thus, the collective decision differentiates secession from other processes that lead to the formulation of political units.

\section{MEDIA FRAMING THEORY}

"To frame, is to select some aspects of a perceived reality and make them more salient in a communicating text, in such a way as to promote a particular problem definition, causal interpretation, moral evaluation, and/or treatment recommendation for the item described" (Entman, 1993, p. 52). Media framing is a process by which issues are portrayed in the news media. Media frame provides some form of boundaries around a news story, determining what is newsworthy and what is not. It is the "central organising idea for news content that supplies a context and suggests what the issue is through the use of selection, emphasis, exclusion, and elaboration" (Tankard, 2001, p. 100). Frame analysis employs deductive and inductive methods of framing patterns. Deductive frame analysis operationalises frames prior to the analysis of the texts in order to examine the extent to which the frames occur in the news (de Vreese, 2005).

\section{MEDIA FRAMING OF CONFLICTS}

The activities of secessionist movements attract public interest both locally and internationally. Secessionists and groups in conflicts always seek coverage by the media in order to gain attention (Vladisavljević, 2015) both nationally and globally. They do that bearing in mind that the media are the best channel for most people in the society who seek for information on politics, conflicts and other events. By framing events and conflicts, the media influence the opinions, views and behaviour of the masses. The framing activities of the media entail reporting conflict situations in a particular way with the potential to influence the dynamics and understanding of that conflict. That could also inform the success or failure of objective for parties in conflict. Thus, "that is why participants in conflicts - including state officials, armed rebels and other 
warring sides, political parties, social movements, workers on strike and pro-democracy activists in authoritarian states - aim to exploit the media to foster their goals by adapting their activities to the logic of media operation" (Vladisavljević, 2015, p. 5). Several studies have investigated the way the media frame conflict situations. According to Somerville (2017), the process of selection of stories and the angles of approach involve frames - frames are in the journalistic sense ways of fitting stories into simple contexts that let the audience know how to interpret them according to existing knowledge and value systems.

The mass media in Nigeria play crucial roles in the framing of events and conflicts by choosing words, phrases, literal techniques as well as the influence of placement on audience perception (Amenaghawon, 2017). For instance, Nwafor and Ogbodo (2016) investigated how the Daily Sun and Leadership newspapers framed the group identities in the 2014 national dialogue in Nigeria which aimed at finding solution to the series of conflicts bedeviling Nigeria. The study found that there was low coverage of the conference in the two newspapers with most of the stories lacking in-depth analysis. The newspapers also framed the stories with sectional undertones; and many of the reports showed unsupportive slants to opposing ethnic groups' viewpoints on the conference; while dominant frames were issues of sectional interests such as power rotation, creation of additional states for equity, religion, state police, security and secession. The study advocated greater media interest in issues of national significance, and intensified crusade for national cohesion; it urges the media to lead the campaign by example; and suggests a review of the Code of Ethics for Nigerian Journalists to stress nationalism as against sectionalism in media reportage.

Furthermore, Amenaghawon (2017) examined the framing techniques, news formats used, sources of frames as well as influence of ownership on the selected Nigerian newspapers in the coverage of the Niger Delta, a conflict that is at the very centre of Nigeria's economy. Findings revealed that the selected newspapers used more of thematic frames than episodic frames, while they also preferred news formats to other editorial formats. In addition the newspapers depended mainly on their government and correspondents for frames used in the coverage of the Niger Delta conflict.

Somerville (2017) found that between the Second World War and 1990, the media usually frame conflicts from Cold War frame. However, conflicts such as the Nigeria Biafran war was not framed from Cold War frame. The war was framed from both humanitarian and tribal frames. Many other conflicts were framed from either tribal or humanitarian frames. For instance the Ethiopian famine and attendant war in Eri- 
trea and Tigre were mainly framed from humanitarian angle.

Furthermore, Vladisavljević (2015) observed that the media's framing of war often emanate from the perspective of its country of origin. The media and public usually employ a nationalist/patriotic frame which supports the operation of the country's armed forces, thus reducing any form of attendant criticism of the conflict actors. For instance, the U.S. media represented the Vietnam War as a 'national endeavor' which captured the conflict as our war. "The same themes applied in the coverage of the 1991 Iraq War, probably to an even greater extent than in the Vietnam War's early years" (Hallin, 1994, p. 53).

Wahutu (2018) investigated the representation of the conflict in Darfur by the media in Kenya, South Africa, Egypt and Rwanda by analyzing 850 newspaper articles published from 2003 to 2008 and interviewing journalists from Kenya and South Africa. Employing Mbembe's articulation of 'meaningful acts' and Bourdieu's field theory, exposed that African media framed the Darfur conflict on the basis of the intersection of geopolitics, symbolic affirmation of unity and 'Africanness' and a ritualistic use of official. The study found that the media in the four countries represented the violence in Darfur from ethnic conflict frame. However, the African media employed ethnic conflict frame in a different way from the Western media which assumed that there is a determined relationship between tribe and conflict. African media employed ethnic frame to separate the actors in the conflict and also localized the news among their audience.

Similarly, Durga (2004) examined the frames used by the U.S. print media - The New York Times, The Washington Post and the Los Angeles Times - in their coverage of the Kashmir conflict and the parties involved in it from 1989 to 2003. The study identified sources and keywords from 180 news reports and placed them into categories from which it isolated thematic clusters or frames. It broke the 15 years of media coverage into four phases and with a focus on the coverage of seven subjects. The researcher found that in the first two phases of the coverage, the conflict was viewed as a violent separatist movement and later was viewed as an ongoing violent conflict between India and Pakistan. The predominant frame through all the phases was the identification of Kashmiris as armed militants who are fighting to secede from India. The Indians were framed as suppressing the Kashmiris through their armed forces, a frame which shifted later to the armed forces being perceived as fighting Pakistani army and non- Kashmiri Islamic fighters. Durga states: 
Pakistan was consistently identified as a country supporting the Kashmiri separatist movement with arms and training, and later as a country itself participating in the conflict through its military. The United States was consistently described as a country concerned with peace and security in South Asia. The dominant frames in all periods were found to be portraying the conflict as a war and in the last two phases, a potential nuclear war. The Indians, Pakistanis and Kashmiris were always characterized through their religious identities - Indians as Hindu, and Pakistanisand Kashmiris as Muslim or Islamic. (2004, p. 8)

Thus, the media framed the conflict through religious, violent separatist, armed militant and war frames. The implication is that the media always cover conflicts through different frames and these frames help to shape the opinion of the public about any raging conflict.

\section{RESEARCH QUESTIONS}

The underneath research questions were raised and answered in this research:

1. How did selected newspapers frame the renewed Biafran agitation?

2. What is the most dominant frame of the renewed Biafran agitation in selected newspapers?

3. What are the frame sources adopted by selected newspapers in the framing of the renewed Biafran agitation?

\section{METHODOLOGY}

This study employs quantitative and qualitative method of research. Content analysis is employed for the gathering of data from the online versions of Daily Trust and Punch newspapers. Content analysis offers the best means to investigate media content. According to Kerlinger (2000) it is "a method of studying and analyzing communication in a systematic, objective, and quantitative manner for the purpose of measuring variables" (as cited in Wimmer \& Dominick, 2006, p. 150). The data were analyzed quantitatively and qualitatively. The data for the quantitative content analysis were 
gathered through purposive sampling technique while the data for the qualitative content analysis were collated through critical case sampling technique which enables the selection of the samples that offer the critical information that is needed for analysis.

\section{THE SAMPLE AND UNIT OF ANALYSIS}

The universe of the study is composed of Nigerian national daily newspapers. This study employs Daily Trust and Punch newspapers because they are among the most widely read newspapers in Nigeria both online and offline. Daily Trust has its stronghold in the Northern part of Nigeria while Punch newspaper is produced in the Southern part of Nigeria. Based on available statistics, they are among the ten best newspapers in terms of online readership in Nigeria (Emeka, 2017). Thus, this study gathered data from January, 2016 to December, 2017 issues of Daily Trust and Punch newspapers. The online version of Daily Trust and Punch newspaper were used for this study due to the fact that both newspapers have plenty online reading audience and also possesses good database for searching up articles.

In order to eliminate bias and be more objective, only news reports and feature articles were analyzed in this research. This is because of the inherent bias that is associated with opinionated editorials, letters to the editor and commentaries. Self-opinionated articles or articles that made simple references to Biafra were not included in the sample.

To generate the sample for this study, Daily Trust and Punch newspapers' archives were searched with the keyword "Biafra". Articles and stories on Biafra were selected for data analysis. The unit of analysis in this study is the complete article or story excluding illustrations, photographs and other visuals associated with the text. The analysis timeframe is from issues dating from January, 2016 to December, 2017. This two-year period saw a spike in the activities of IPOB and other related groups that champion the Biafran cause. The leader of IPOB, Nnamdi Kanu was released from prison during this period and he went around creating awareness. The group also issued ultimatum to the Federal government demanding a referendum for the determination of the Biafran nation. Within the same period, the group also called for the boycotting of election in the entire Igbo land, starting from Anambra state election in November, 2017. All the forgoing events offered journalists and reporters enough materials to report the Biafran cause from different perspectives and constantly fed the public with information on the Biafran issue. 


\section{CONCEPTUAL CLARIFICATION}

A frame provides boundaries around a news story, determining what is newsworthy and what is not. It is the "central organizing idea for news content that supplies a context and suggests what the issue is through the use of selection, emphasis, exclusion, and elaboration" (Tankard, 2001, p. 100). It offers special angle to a story or event. Six (6) frames were identified in this study. They are described below.

Political frame describes how political parties blame each other for the renewed agitation of Biafrans.

Economic frame captures the role of the economy in the agitation for Biafran nation. It also refers to the direct impact of the struggle on the economy.

Separatist frame refers to the quest to cut off the Igbo nation from Nigeria. It has ethnic twist.

Human rights frames show physical and psychological abuse of members of the Biafran movement by Nigerian security agencies.

Conflict frame describes the conflict between opposing interest groups like the Nigerian government and the Biafran agitators. The potential danger of the continuous agitation is the militarization of South East Nigeria and arrests of Biafran movement members.

Hate Speech frame refers to the verbal attack and counter attacks that often took tribal dimension among Nigerian youths in relation to Biafran agitation.

Frame sources refer to the first two sources cited in the article or stories that were coded to discover who the individuals, institutions or groups attempted to direct the media frames at. This refers to the Nigeria government, correspondents, elder statesmen, agitators, international community, and NGOs.

Valence refers to the twist or orientation of the frame. It shows whether Biafran agitation was captured as positive or negative event. It could also be neutral when the article does not state the benefits or disadvantages associated with the Biafran struggles.

\section{INTERCODER RELIABILITY}

In order to maintain the reliability and validity of this study, an inter-coder reliability test was conducted on the units of stories related to Biafra from Daily Trust and Punch newspaper websites. Inter-coder reliability is the level of agreement among the 
coders who employ the same instrument in the coding of similar content (Wimmer and Dominick, 2006).This study employed Holsti's 1969 formula for inter-coder reliability which is:

$$
\mathrm{R}=2 \mathrm{M} / \mathrm{N} 1+\mathrm{N} 2 \text {. }
$$

$\mathrm{M}$ is the number of coding decisions that the coders agreed on; and N1 and N2 refer to the numbers of coding decisions made by the first and second coder. In this study, the two coders coded a total of 421 units of newspaper stories and agreed on 411 of them. A satisfactory inter-coder reliability is achieved when the coefficient is above .85 (Wang, 2011, p. 18). For this study, the inter-coder reliability coefficient is 0.976.

$$
\mathrm{R}=2 \times 411 / 421+421
$$

$\mathrm{R}=.976$, rounded up to 2 decimal places $=0.98$ inter-coder reliability coefficent.

\section{RESULTS AND DISCUSSION OF FINDINGS}

A total of 421 articles that discussed the Biafran agitation were collected from Daily Trust and Punch newspaper website over a two-year period from 2016 to 2017. This period marked heightened activities by members of Indigenous People of Biafra and other activists calling for a breakup of the Igbo nation from Nigeria.

\section{RESEARCH QUESTION ONE: HOW DID SELECTED NEWSPAPERS FRAME THE RENEWED BIAFRAN AGITATION?}

This study identified the following frames in the portrayal of Biafran agitation in Daily Trust and Punch newspaper online editions: political, economic, separatist, human rights, conflict and hate speech frames. These are described below:

1. Political frame discusses the political angle of the Biafran agitation. It underscores the quest for power and self-rule of the desired new nation by members of the 
IPOB and other groups calling for Biafra such as Movement for the Actualisation of the Sovereign State of Biafra (MASSOB). Both Daily Trust and Punch newspaper employed this frame.

Extract 1. In the quest for political relevance, the Biafran agitator chose to fix a date for independence of the Biafran nation. The Movement for the Actualisation of the Sovereign State of Biafra has declared May 22 as Biafra Independence Day across the country, urging all Igbos worldwide to join in the celebration... The statement reiterated the groups desire to peacefully achieve the dream of Biafra Republic, adding the Igbos were no longer comfortable with the 'unholy marriage', which it claimed had suffocated the progress and innovativeness of the Igbo (Punch 2017, May 8).

Extract 2. Due to the fear of losing their political strongholds, state governors in the South Eastern Nigeria refused to support the Biafran agitation. Nnamdi Kanu said that in realisation of this, South-East governors were afraid of losing their positions and political relevance in the area. He said that was why the governors in the zone were not supporting the Biafra struggle (Punch 2017, May 15). The leadership of the Indigenous People of Biafra (IPOB) headed by Mazi Nnamdi Kanu yesterday rejected the plea of the governors of the South-East to drop the Biafran agitation (Daily Trust 2017, August 30).

Extract 3. Governors of the South-East and South-South state held a political meeting over Biafra agitation. Governors of the South-East and South-South states held a crucial meeting in Enugu on Sunday night... the meeting was informed by the ongoing agitation for Biafra in parts of the two zones. The meeting came on the heels of an earlier meeting between the South-East governors and some Igbo leaders, including the leadership of the Ohanaeze Ndigbo and the South-East National Assembly Caucus, where they declared their support for a 'united Nigeria.' (Punch 2017, July 10). Imo State Governor Rochas Okorocha yesterday took a swipe at the leader of the Indigenous People of Biafra (IPOB), Nnamdi Kanu for his Biafra agitation (Daily Trust 2017, June 29).

2. Economic frame captures the angle of the economy in the agitation for Biafra. It shows the role of the economy in the struggle. It could also imply the direct impact of the struggle on the economy of activists involved or on Nigeria.

Extract. Nigerian government decided to make the life of former Biafran security agents better through the payment of their long-held pension. The payment of the pension was flagged off at an elaborate ceremony in Enugu on Friday. The affected police personnel were part of the Nigerian Police Force before the outbreak of the war 
Examining Selected Newspapers' Framing of the Renewed

Biafran Agitation in Nigeria (2016 - 2017)

but found themselves on the Biafran side when the war commenced. They were initially dismissed from service after the war before the former President Olusegun Obasanjo granted them amnesty in 2000 by converting their dismissal to retirement with full benefits. Despite the amnesty, the ex-policemen have yet to receive their full entitlements, until President Muhammadu Buhari approved the payment of their pension through the Pension Transitional Arrangement Directorate (Punch 2017, October 20).

In particular, these agitations have been most pronounced in the South-east, where the activities of various pro-Biafra groups have been most pronounce... South-east's political future should therefore be put in context of its economic interest and survival. The Igbos have larger chunk of their investments outside the South-east. Our people have invested heavily in every nook and cranny of Nigeria. They are into trading. Imagine a situation where a Republic of Biafra would have to depend on Nigerian passports to travel out (Daily Trust 2017, September 22).

3. Separatist frame shows the attempt by the Biafran activist to severe Igbo nation from Nigeria. This has ethnic twist and security threat.

Extract. A separatist group sets up apparatus that makes it a state. Also, some Igbo groups disagree with the agitation of separating from Nigeria. A video showing the leader of the Indigenous People of Biafra, Nnamdi Kanu, inspecting the 'Biafra Secret Service' has gone viral on the internet.The video showed some of the purported 'BSS officers' dressed in black attire and red beret. Kanu could be seen walking around and in between them, inspecting what can be described as a guard of honour (Punch, 2017 August 16). Ralph Uwazurike, leader, Movement for the Actualisation of the Sovereign State of Biafra (MASSOB), says the activities of Independent People of Biafra (IPOB) negate the rule of engagement of the Biafra struggle. He said the interest of the Biafra movement was to secure the interest, lives and property of Igbo people and not to start another war (Daily Trust 2017, September 13).

4. Human rights frames captures the physical and psychological abuse of members of the Biafran movement by Nigerian security agencies.

Extract 1. Many of the Biafran activists faced suppression from the government. In addition, top sources in the police told Saturday PUNCH that the security agency had placed the leader of the Indigenous People of Biafra, Nnamdi Kanu, under surveillance to prevent him from fleeing the country should the court revoke his bail and order his rearrest for allegedly flouting his bail conditions (Punch 2017, September 2). The Police 
yesterday arraigned 45 supporters of the Indigenous People of Biafra (IPOB) who were arrested last Friday during a rally (Daily Trust 2017, January 24).

Extract 2. Many Biafran agitators were massacred by the government. The Indigenous People of Biafra on Wednesday attacked the All Progressives Grand Alliance for calling its leader, Nnamdi Kanu, a maximum emperor. It alleged that APGA as a government had at several times killed no fewer than 2000 of its members in Anambra State (Punch 2017, June 28).

5. Conflict frame portrays the conflict between opposing interest groups like the Nigerian government and the Biafran agitators.

Extract 1. The Biafran activists agitated against the federal government of Nigeria. The sit-at-home protest ordered by pro-Biafra groups, the Movement for the Actualization of the Sovereign State of Biafra and the Indigenous People of Biafra, to commemorate the 50th anniversary of the defunct Biafra nation recorded substantial compliance in Enugu on Tuesday (Punch 2017 May 30).

Extract 2. Some form of crisis hit the agitators clamouring for the Biafran nation. Crisis seems to have hit agitators for South East country as the main group, Movement for the Actualization of the Sovereign state of Biafra, backs out of celebration slated for Monday. MASSOB has also disowned its founder, Chief Ralph Uwazurike, as well as cautioned that it was not affiliated to any group called Biafra Independent Movement (Punch, 2017 May 22). The Igbo community in Adamawa state says agitations for Biafra republic is unnecessary (Daily Trust 2017, September 21).

6. Hate Speech frame portrays the exchange of diatribe between Igbo youths who support the cause of the Biafran movement and other youths from other parts of Nigeria are against the Biafran movement. Both Daily Trust and Punch newspapers framed the conflict from hate speech frame.

Extract 1. Some Arewa (Hausa) youths threatened Igbo people living in the North over the activities of Biafran agitators led by Mazi Nnamdi Kanu. The youths asked the Igbos in the North to leave the North if the Biafran agitation persisted. Exchange of words led to hate speeches on social media. The Eze N'digbo (traditional rulers) and leaders of Igbo socio-cultural associations in the North have vowed to resist any attempt by the Coalition of Northern Groups to chase them out of the region. The coalition groups are: Arewa Citizens Action for Change, led by Nastura Ashir Sharif; Arewa Youth Consultative Forum, led by Shettima Yerima; Arewa Youth Development Foun- 
dation, led by Aminu Adam; and the Arewa Students Forum, led by Alfred Solomon (Punch 2017, June 11).

Extract 2. The Federal Government and concerned bodies tried to contain the hate speech. Acting President Yemi Osinbajo has warned that persons agitating for secession and the northern groups that issued ultimatum to Igbo risked jail terms as they violated Nigeria's laws. Osinbajo gave the warning at a consultative meeting with traditional rulers from the South-East at the Presidential Banquet Hall, Abuja, on Sunday (Punch 2017, June 18).

The President-General of Ohanaeze Ndigbo, Chief Nnia Nwodo, has expressed dismay over the spate of hate speech on social media platforms by Igbo youths under the guise of agitating for Biafra. He said that making inciting speech was capable of causing crisis which could lead to mass violence in the nation, adding that it was pertinent to respect constituted authorities (Punch 2017 October 5). The Indigenous People of Biafra has cautioned former Head of State, Yakubu Gowon over his recent comments against the late Dim Odimegwu Ojukwu that lies by the late warlord, Odumegwu Ojukwu led to Nigerian Civil war... any attempt to rewrite the history of Biafra-Nigeria war will be intellectually resisted (Daily Trust 2017, October 25).

Findings from the foregoing show that both Daily Trust and Punch newspapers employed political, economic, separatist, human rights, conflict and hate speech frames in the portrayal of the renewed Biafran agitation. The findings support the assumption that secession is rational choice which is an "outcome of series of collective decisions made by regional leaders and populations, and by the leaders and populations of host states" (Hecter, 1992, p. 1). The Biafran agitators consciously seek separation from the Nigerian state. However, the findings of this study show that media framing of the Biafran movement did not tie the secession movement to ethnic frame. This does not offer support to some studies (Hentschel, 2018; Criado, Herreros, Miller, \& Ubeda, 2018) which underscore ethnicity as a key ingredient in secession movements. 


\section{RESEARCH QUESTION TWO: \\ WHAT IS THE MOST DOMINANT FRAME OF THE RENEWED BIAFRAN AGITATION IN SELECTED NEWSPAPERS?}

The dominant frame refers to the frame that occurred most in the 2-year editions of the Daily Trust and Punch newspaper from 2016 to 2017. Table 2 shows the adopted frames and the rate of their occurrence in selected newspaper.

Table 2

Adopted Frames in Selected Newspapers, 2016 - 2017

\begin{tabular}{lccc}
\hline Frames & Daily Trust (\%) & Punch (\%) & Total (\%) \\
\hline Political Frame & $37(8.8 \%)$ & $30(7.1 \%)$ & $67(15.9 \%)$ \\
Economic Frame & $23(5.5 \%)$ & $6(1.4 \%)$ & $29(6.9 \%)$ \\
Separatist Frame & $47(11.2 \%)$ & $52(12.3 \%)$ & $99(23.5 \%)$ \\
Human rights Frame & $78(18.5 \%)$ & $89(21.2 \%)$ & $167(39.7 \%)$ \\
Conflict Frame & $11(2.6 \%)$ & $27(6.4 \%)$ & $38(9.0 \%)$ \\
Hate Speech Frame & $9(2.1 \%)$ & $12(2.9 \%)$ & $21(5.0 \%)$ \\
\hline \multicolumn{2}{c}{} \\
\hline
\end{tabular}

Finding from Table 2 shows that the most dominant frame was the human rights frame with $39.7 \%$. That was followed by the separatist frame which accounted for $23.5 \%$ of the entire frames adopted by selected newspapers. Political frame accounted for $15.9 \%$ of the entire adopted frames. Conflict frame was the next with $9.0 \%$ of the entire adopted frames. The implication of the foregoing is that several Biafran agitators were maimed, wounded and others were killed by Nigerian security forces. They were abused and dehumanized. Also, the agitators clamour for a separation from Nigeria in order to form the Republic of Biafra.

The most dominant frame which is human rights frame is supported by the data from the Nigeria Watch database as captured in Figure 1. The chart indicates that about 1,112 persons have lost their lives in the Biafran movement. About $95 \%$ of the fatalities were as a result of extra-judicial killings by the Nigerian security operatives comprising of the Nigerian Army, Nigerian Police and the Nigeria Security and Civil Defence Corps (NSCDC). The Secessionists and other groups in conflicts always seek coverage by the media in order to gain attention (Vladisavljević, 2015). This study 
established that human rights is the dominant frame adopted by selected newspapers. This is different from the findings of Durga (2004) which shows that in period of study of the Kashmir conflict, the most dominant frame through all the phases was the identification of Kashmiris as armed militants who are fighting to secede from India. That is a separatist frame. Thus, secession movements are framed from different angles by selected newspapers.

\section{RESEARCH QUESTION THREE: WHAT ARE THE FRAME SOURCES ADOPTED BY SELECTED NEWSPAPERS IN THE FRAMING OF THE RENEWED BIAFRAN AGITATION?}

Frame sources refer to those who were most frequently cited as the source of the news story.

This refers to IPOB, MASSOB, correspondents, Nigerian government, Other Nigerians, Igbo leaders, elder statesmen, International Community and NGOs. Table 3 shows the frames sources of articles and news stories on Biafran agitation in Daily Trust and Punch newspapers from January 2016 - December, 2017.

Table 3

Frame Sources of Biafran Stories in Selected Newspapers, $2016-2017$

\begin{tabular}{|c|c|c|c|}
\hline Frames Sources & Daily Trust (\%) & Punch (\%) & Total (\%) \\
\hline MASSOB & $5(1.2 \%)$ & $13(3.1 \%)$ & $18(4.3 \%)$ \\
\hline IPOB & $30(7.1 \%)$ & $21(5.0 \%)$ & $51(12.1 \%)$ \\
\hline Other Biafra Groups & $16(3.9 \%)$ & $12(2.8 \%)$ & $28(6.7 \%)$ \\
\hline Correspondents & $43(10.2 \%)$ & $69(16.4 \%)$ & $112(26.6 \%)$ \\
\hline Nigerian government & $32(7.6 \%)$ & $49(11.6 \%)$ & $81(19.2 \%)$ \\
\hline Other Nigerians & $33(7.8 \%)$ & $13(3.1 \%)$ & $46(10.9 \%)$ \\
\hline Igbo leaders & $10(2.4 \%)$ & $14(3.3 \%)$ & $24(5.7 \%)$ \\
\hline Elder statesmen & $11(2.6 \%)$ & $9(2.2 \%)$ & $20(4.8 \%)$ \\
\hline NGOs & $12(2.8 \%)$ & $5(1.2 \%)$ & $17(4.0 \%)$ \\
\hline \multirow[t]{2}{*}{ International Community } & $11(2.6 \%)$ & $13(3.1 \%)$ & $24(5.7 \%)$ \\
\hline & $205(48.7 \%)$ & $216(51.3 \%)$ & $421(100 \%)$ \\
\hline
\end{tabular}


Findings from Table 3 reveal that the frame source for Biafra agitation stories in selected newspaper was mainly newspaper correspondents which accounted for $26.6 \%$ of the entire frame sources. That is followed by the Nigerian government which accounted for $19.2 \%$ of the entire frame sources. IPOB is the next frame source which represents $12.1 \%$ of the entire frame sources. The least frame source is the Non-Governmental Organizations (4.0\%) such as Amnesty International and others. The implication of the findings is that Daily Trust and Punch newspapers depended more on their correspondents for frames about the Biafran agitation within the twoyear period from 2016 to 2017. Relying on various sources for frames offers richer perspective to the news coverage.

The findings of this study show that the main frames sources were correspondents. This is in alignment with work of Amenaghawon (2017) which examined selected Nigerian Newspapers in the coverage of the Niger Delta, a conflict that is at the very centre of Nigeria's economy. Findings revealed that the selected newspapers depended mainly on the government and media correspondents for frames used in the coverage of the Niger Delta conflict. Media houses have correspondents. Similarly, Somerville (2017) found that between the Second World War and 1990, the media usually frame conflicts from Cold War frame. However, conflicts such as the Nigeria Biafran war was not framed from Cold War frame. The war was framed by media correspondents from both humanitarian frame. The renewed Biafran agitators are faced with the same humanitarian situation.

\section{CONCLUSION}

The media portray issues in the society from different angles. Through the use of different frames which depict the voice of the media, the activities of Biafran activists were reported to the audience. The media shape the minds and opinion of the audience on the events in the society. Daily Trust and Punch newspapers framed Biafran agitation from 2016 to 2017 from political, economic, separatist, human rights, conflict and hate speech angles. The two years was a period of heightened activities by members of IPOB and also MASSOB. In addition, the selected print media portrayed human rights abuse as the most dominant issue that is related to the Biafran agitation. Many of the Biafran activists were manhandled and many were killed by Nigerian security agents like the police, civil defence corps and army. That creates a moral bur- 
den on the Nigerian government which has refused to dialogue with the agitators. In all, this research exposes how selected print media framed a burning issue which is central to the unity and existence of Nigeria as one nation. The issue of secession has become a big problem in the country. What the media offer to the public determine the opinion of the masses about the issue. Understanding how Biafran agitation is framed by foremost newspapers in Nigeria is very important.

This study recommends that more Nigerian journalists should be trained on how to portray a holistic view on issues about conflict and activism. That will help then to present a more balanced reportage with balanced news frames. They should continue to impress it on the actors in the conflict to find a way to solve the problem. Journalists should be equipped with best practices for engaging in more investigative journalism in order to come up with objective facts through multi-varied sources without presenting issues from only one particular source. That will enrich media coverage and framing of events in the society.

\section{REFERENCES}

Akpan, N. U. (1976). The Struggle for Secession, 1966-1970: A Personal Account of the Nigerian Civil War. (2nd ed., pp. 89-106). Routledge. ISBN 9781317792314.

Amenaghawon, F. (2017). Print Media Framing of the Niger Delta Conflict in Two Selected Nigerian Newspapers. M C C, 1.1 (pp. 88-101). Retrieved March 19, 2019 from http://www.unimaid.edu.ng/Journals/Social\%20Sciences/Masscomm/MCC\%20Vol\%201\%20No\%201\%20June\%202017/MCC\%20Vol\%20 1\%20No\%201\%20Article\%2006.pdf

Amnesty International. (2016). Peaceful Pro-Biara Activists Killed in Chilling Crackdown. Retrieved 15 October, 2017 from https://www.amnesty.org/en/latest/ news/2016/11/peaceful-pro-biafra-activists-killed-in-chilling-crackdown/

Channels Tv. (2017). Federal High Court Proscribes IPOB. Retrieved 19 October, 2017 from https://www.channelstv.com/2017/09/20/federal-high-court-proscribes-ipob/ 
Criado, H., Herreros, F., Miller, L., \& Ubeda, P. (2018). The Unintended Consequences of Political Mobilization on Trust: The Case of the Secessionist Process in Catalonia. Journal of Conflict Resolution, 62(2), 231-253. https://doi. org/10.1177/0022002717723433

Diaz, J. (2017). You Can't Support Catalonia’s Secession Movement If You Were Horrified By Brexit. Retrieved March 03, 2019 from https://www.fastcompany. com/40479515/you-cant-support-catalunyas-secession-movement-if-youwere-horrified-by-brexit

Dixon, R. (2016). Biafra, scene of a bloody civil war decades ago, is once again a place of conflict. 27 November, Los Angeles Times. Retrieved October 20, 2017 from http://www.latimes.com/world/africa/la-fg-nigeria-biafra-20161126-story.html

Durga, R. (2004). Frames in the US print media coverage of the Kashmir conflict. Thesis Submited to School of Mass Communications College of Arts \& Sciences, University of South Florida. Retrieved March 19, 2019 from https://scholarcommons.usf.edu/cgi/viewcontent.cgi?referer=https://scholar.google.com/\&httpsre $\operatorname{dir}=1 \&$ article $=2215 \&$ context $=$ etd

Emeka C. (2017). Top 10 Nigerian Newspapers (Most Read Online). Retrieved October 30, 2017 from https://answersafrica.com/top-10-nigerian-newspapersmost-read-online.html

Entman, R. M. (1993). Framing: Toward Clarification of a Fractured Paradigm. Journal of Communication 43(4), 51-58.

Griffiths, R. (2017). Five secessionist movements to watch in 2018. Retrieved March 03, 2019 from https://sydney.edu.au/news-opinion/news/2017/10/30/five-secessionist-movements-to-watch-in-2018.html

Griffiths, R.D., \& Wasser,L.M.(2018). Does ViolentSecessionism Work? Journal ofConflict Resolution, 63(5), 1310-1336. https://doi.org/10.1177/0022002718783032

Hallin, D. C. (1994). Images of the Vietnam and the Persian Gulf Wars in U.S. Television. In S. Rabinovitz \& S. Jeffords (eds.) Seeing through the Media: The Persian Gulf War (pp. 45-58). New Brunswick, NJ: Rutgers. 
Hecter, M. (1992). The Dynamics of Secession. Acta Sociologica 32, 267-283.

Hegarty, S. (2017). "Biafran leader Nnamdi Kanu: The man behind Nigeria's separatists". BBC Online. London, UK. Retrieved 23 October, 2017 from http://www. bbc.com/news/world-africa-39793185

Hentschel, F. (2018). Unraveling Secessions. Journal of Conflict Resolution. https:// doi.org/10.1177/0022002718792611

Nwafor, K. A., \& Ogbodo, J. N. (2016). Media Frames of Group Identities in the 2014 National Dialogue in Nigeria: An Analysis of the Daily Sun and Leadership Newspapers. International Journal of International Relations, Media and Mass Communication Studies, 2(1), 63-79.

Sari, A. C. (2018, July 26). A neoclassical realist explanation of Indonesia's involvement in Muslim-related secessions in non-Muslim countries. Asian Journal of Comparative Politics. https://doi.org/10.1177/2057891118787930

Somerville, K. (2017). Framing conflict - the Cold War and after: Reflections from an old hack. Media, War \& Conflict, 10(1), 48-58. https://doi. org/10.1177/1750635217698336

Sorens, J. (2005). The Cross-Sectional Determinants of Secessionism in Advanced Democracies. Comparative Political Studies, 38(3). https://doi. org/10.1177/0010414004272538

Tankard, J. W. (2001). The empirical approach to the study of media framing. In S. D. Reese, O. H. Gandy, \& A. E. Grant (Eds.) Framing public life. Mahwah, NJ: Lawrence Erlbaum.

Tir, J. (2005). Keeping the Peace after Secession: Territorial Conflicts Between Rump and Secessionist States. Journal of Conflict Resolution, 49(5), 713-741. https:// doi.org/10.1177/0022002705279426

de Vreese, C. H. (2005). News Framing: Theory and Typology. Information Design Journal and Document Design, 13(1), 51-62. 
Vladisavljevic, N. (2015). Media framing of political conflict: A review of the literature. Media, Conflict and Democratisation. May 2015, 1-35. Retrieved March 17, 2018 from http://www.mecodem.eu/wp-content/uploads/2015/05/ Vladisavljević-2015_Media-framing-of-political-conflict_-a-review-of-the-literature.pdf

Wang, W. (2011). A Content Analysis of Reliability in Advertising Content Analysis Studies. Electronic Thesis and Dissertations. Retrieved February 20, 2019 from https://dc.etsu.edu/cgi/viewcontent.cgi?article $=2566 \&$ context $=$ etd

Wahutu S. J. (2018). Representations of Africa in African media: The case of the Darfur violence. African Affairs, 117(466), 44-61. https://doi.org/10.1093/afraf/ $\operatorname{adx} 039$

Wimmer, R. D., \& Dominick, J. R. (2006). Mass media research (8th ed.). Belmont, CA: Thomson Wadsworth. 